\title{
Nitric Oxide Mediates Angiogenesis In Vivo and Endothelial Cell Growth and Migration In Vitro Promoted by Substance P
}

\author{
Marina Ziche, Lucia Morbidelli, Emanuela Masini, Sandra Amerini, Harris J. Granger,* Carto Alberto Maggi,” \\ Pierangelo Geppetti, $\mathbf{5}$ and Fabrizio Ledda \\ Department of Pharmacology, University of Florence, 50134 Florence, Italy; * Microcirculation Research Institute and Department of \\ Physiology, Texas A\&M University, College Station, Texas 77843-1114; ${ }^{\ddagger}$ Pharmacological Department, A. Menarini Pharmaceuticals, \\ 50131 Florence, Italy; and ${ }^{8}$ Institute of Internal Medicine IV, University of Florence, 50134 Florence, Italy
}

\begin{abstract}
We evaluated the effects of nitric oxide (NO) generators and endogenous production of NO elicited by substance P (SP) in the angiogenesis process. Angiogenesis was monitored in the rabbit cornea in vivo and in vitro by measuring the growth and migration of endothelial cells isolated from coronary postcapillary venules. The angiogenesis promoted in the rabbit cornea by [Sar']-SP-sulfone, a stable and selective agonist for the tachykinin $\mathrm{NK}_{1}$ receptor, and by prostaglandin $\mathrm{E}_{1}\left(\mathrm{PGE}_{1}\right)$, was potentiated by sodium nitroprusside (SNP). Conversely, the NO synthase inhibitor $\mathbf{N}^{\omega}$-nitro-Larginine methyl ester (L-NAME), given systemically, inhibited angiogenesis elicited by [Sar $\left.{ }^{9}\right]-S P$-sulfone and by PGE $_{1}$. Endothelial cells exposed to SNP exhibited an increase in thymidine incorporation and in total cell number. Exposure of the cells to NO generating drugs, such as SNP, isosorbide dinitrate, and glyceryl trinitrate, produced a dose-dependent increase in endothelial cell migration. Capillary endothelial cell proliferation and migration produced by SP were abolished by pretreatment with the NO synthase inhibitors $\mathbf{N}^{\omega}$-mono-methyl-L-arginine (L-NMMA), $\mathbf{N}^{\omega}$-nitro-L-arginine (L-NNA), and L-NAME. Exposure of the cells to SP activated the calcium-dependent NO synthase. Angiogenesis and endothelial cell growth and migration induced by basic fibroblast growth factor were not affected by NO synthase inhibitors. These data indicate that NO production induced by vasoactive agents, such as SP, functions as an autocrine regulator of the microvascular events necessary for neovascularization and mediates angiogenesis. (J. Clin. Invest. 1994. 94:2036-2044.) Key words: neovascularization • endothelium • vasodilation • nitrovasodilator $・$ tachykinin
\end{abstract}

\section{Introduction}

Angiogenesis is the process of new vessel generation which leads to neovascularization (1). In the adult tissue, angiogenesis is of importance for various physiological and pathological processes such as ovulation and corpus luteum formation, healing processes including recovery from myocardial infarction, tumor

Address correspondence to Marina Ziche, M.D., Department of Pharmacology, Viale Morgagni 65, 50134 Florence, Italy.

Received for publication 8 December 1993 and in revised form 20 July 1994.

J. Clin. Invest.

(c) The American Society for Clinical Investigation, Inc. 0021-9738/94/11/2036/09 \$2.00

Volume 94, November 1994, 2036-2044 growth and metastasis, chronic arthropathies, and diabetic retinopathies.

The morphogenesis of capillaries involves a concerted sequence of events usually described as mobilization of the endothelium in a controlled direction, cellular proliferation, canalization of a solid bud, and production of the periendothelial stroma (2).

Although a large number of vasoactive-vasodilating agents are reported to possess angiogenic activity (3-6) the relevance of vasodilation to the angiogenesis process is largely unknown. Endothelium-dependent vasodilation has been clearly demonstrated to be caused by the endothelium-derived relaxing factor identified as nitric oxide $(\mathrm{NO})^{1}(7,8)$ which acts at the cellular level by increasing cyclic guanosine monophosphate (GMP) (9).

The tachykinin substance P (SP) is released when noxious stimuli activate the peripheral endings of primary sensory neurons, causing vasodilation and increased vascular permeability (10). The vasorelaxant response to SP is endothelium dependent and is mediated by $\mathrm{NK}_{1}$ receptors $(11,12)$. Recently we have shown that SP activates cyclic GMP production in the capillary endothelium (13) and that NO-generating drugs promote endothelial cell proliferation in vitro (14). Furthermore, reports from our group and others have indicated that $\mathrm{SP}$, via $\mathrm{NK}_{1}$ receptors, promotes angiogenesis in vivo, endothelial cell growth, and mobilization in vitro (15-17). These observations have lead us to hypothesize that there is a link between NO production from capillary endothelium and angiogenesis. In the present study we have investigated the role played by NO in the angiogenesis process promoted by SP. Angiogenesis was studied in vivo using the rabbit cornea assay and in vitro on capillary endothelial cells.

\section{Methods}

Angiogenesis in vivo: rabbit cornea assay. The angiogenic activity was assayed in vivo using the rabbit cornea assay (18). Angiogenesis was studied in the cornea of albino rabbits since this is an avascular and transparent tissue where inflammatory reactions and growing capillaries can be easily monitored and changes quantitated by stereomicroscopic examination (19). Slow-release pellets $(1 \times 1 \times 0.5 \mathrm{~mm})$ were prepared in sterile conditions incorporating the test substances into a casting

1. Abbreviations used in this paper: Ach, acetylcholine; bFGF, basic fibroblast growth factor; CVEC, coronary venular endothelial cells; GMP, guanosine monophosphate; GTN, glyceryl trinitrate; ISDN, isosorbide dinitrate; L-NAME, $\mathrm{N}^{\omega}$-nitro-L-arginine methyl ester; LNMMA, $\mathbf{N}^{\omega}$-mono-methyl-L-arginine; L-NNA, $\mathbf{N}^{\omega}$-nitro-L-arginine; $\mathrm{MeB}$, methylene blue; NA, noradrenaline; $\mathrm{NO}$, nitric oxide; $\mathrm{PGE}_{1}$, prostaglandin $E_{1} ; S N P$, sodium nitroprusside; SP, substance $P$. 
solution of an ethynyl-vinyl copolymer (Elvax-40), in $10 \%$ methylene chloride (10 $\mu \mathrm{l} /$ droplet). In the lower half of New Zealand White rabbit eye (Charles River, Calco, Como, Italy), anesthetized by sodium pentothal $(30 \mathrm{mg} / \mathrm{kg})$, a micro pocket $(1.5 \times 3 \mathrm{~mm})$ was surgically produced using a pliable iris spatula $1.5 \mathrm{~mm}$ wide. The pellets were implanted in the micropockets located in the transparent avascular corneal stroma. Subsequent daily observations of the implants were made with a slit lamp stereomicroscope without anesthesia. An angiogenic response was scored positive when budding of vessels from the limbal plexus occurred after 3-4 d and capillaries progressed to reach the implanted pellet according to the scheme previously reported (18). Angiogenic activity was expressed as the number of implants exhibiting neovascularization over the total implants studied. Potency was scored by the number of newly formed vessels and by their growth rate. Data were expressed as angiogenesis score, calculated as vessel density $\times$ distance from limbus in $\mathrm{mm}$. A density value of 1 corresponded to 0 to 25 vessels per cornea; 2 , from 25 to $50 ; 3$, from 50 to $75 ; 4$, from 75 to 100 ; and 5 , for more than 100 vessels.

Experimental designs. (a) To test the potentiation of the angiogenic response by NO generator, two adjacent pockets were surgically produced in the same cornea, one bearing the angiogenic trigger and the other sodium nitroprusside (SNP) or control. Prostaglandin $\mathrm{E}_{1}\left(\mathrm{PGE}_{1}\right)$ and a stable analogue of SP, [Sar $\left.{ }^{9}\right]$-SP-sulfone which selectively activates tachykinin $\mathrm{NK}_{1}$ receptors (20), were tested at doses of $0.1 \mu \mathrm{g}$ and $0.5 \mu \mathrm{g} /$ pellet, respectively, which produced a weak angiogenic response as previously reported $(3,15)$. Pellets containing $1 \mu \mathrm{g}$ SNP were used to potentiate angiogenesis. Pellets of Elvax alone were used as control.

(b) To evaluate the effect of NO synthase inhibition on the response to the angiogenic effectors, $\mathbf{N}^{\omega}$-nitro-L-arginine methyl ester (L-NAME) or the inactive enantiomer $\mathbf{N}^{\omega}$-nitro-D-arginine methyl ester (D-NAME) (23) were given in the drinking water ad libitum. Drug solutions $(0.5$ $\mathrm{g} / \mathrm{l}$ ) were freshly prepared daily. Water intake was $\sim 200 \mathrm{ml} / \mathrm{d}$ in the treated animals and was not different from the control group. Animals were kept under treatment 1 wk before surgery and $10 \mathrm{~d}$ after corneal implant. The effect of L-NAME treatment was compared with the treatment with both D-NAME and vehicle alone. Corneas were implanted with $\mathrm{PGE}_{1}$ at the dose of $0.25 \mu \mathrm{g}$, [Sar']-SP-sulfone at the dose of 1 $\mu \mathrm{g}$, and Elvax alone in all the three groups. A second group of animals, treated with L-NAME, received corneal implants of pellets containing basic fibroblast growth factor (bFGF, $0.1 \mu \mathrm{g} /$ pellet) or Elvax. A group of five rabbits receiving L-NAME treatment for $10 \mathrm{~d}$ was returned to normal diet for $2 \mathrm{wk}$ and then tested for angiogenesis.

Platelet aggregation and cyclic nucleotide levels. Blood samples from control, D-NAME, and L-NAME-treated rabbits were taken 10 and $18 \mathrm{~d}$ after beginning of the treatment. In three animals blood samples were also taken $21 \mathrm{~d}$ after discontinuation of the treatment. Washed rabbit platelets were prepared as described by Radomski and Moncada (22), with minor modifications. Indomethacin $(10 \mu \mathrm{M})$ was added to the final platelet suspension to prevent the formation of cyclooxygenase products. The platelet count was adjusted to $\sim 1.5-2 \times 10^{8} / \mathrm{ml}$. A suspension of washed platelets was incubated at $37^{\circ} \mathrm{C}$ for $4 \mathrm{~min}$ in a Payton dual channel aggregometer with continuous stirring at $1,000 \mathrm{rpm}$ and then stimulated with thrombin $(40-60 \mathrm{mU} / \mathrm{ml})$ to give a submaximal aggregation (80-90\%). The decrease in optical density was recorded for $5 \mathrm{~min}$ and data were expressed as percent of platelet aggregation obtained with platelets of control animals. To measure cyclic GMP levels, $500 \mu \mathrm{l}$ of 5\% TCA were added to the samples of stirred and nonstirred platelets. TCA from the supernatant was extracted with 0.5 $M$ tri- $n$-octylamine dissolved in 1,1,2 trichloro-trifluoroethane. Levels of cyclic GMP in the aqueous phase were measured by radio-immunoassay in duplicate with prior acetylation of samples with acetic anhydride using iodinated tracer (13).

Aortic ring's vasorelaxant response. The effect of systemic LNAME in inhibiting endothelium-dependent vasorelaxation was tested after $18 \mathrm{~d}$ of treatment. Rabbits were killed by sodium pentothal overdose. The thoracic aorta, cleaned of adhering fat and connective tissue, was cut into 3-3.5-mm-wide transverse rings. Each aortic ring was mounted in an organ bath by means of two triangle-shaped stainless steel wires. The lower wire was fixed to the bottom of the chamber, while the upper wire was connected to the force transducer. The rings were suspended under a tension of $2 \mathrm{~g}$ and isometric force of contraction was measured and recorded on a chart recorder. The preparations were allowed to equilibrate for at least $1 \mathrm{~h}$ in a gassed solution $\left(95 \%, \mathrm{CO}_{2}\right.$ $5 \%$ ) at $37^{\circ} \mathrm{C}$ with a Krebs solution with the following composition (mM): $\mathrm{NaCl} 115, \mathrm{KCl} 4.7, \mathrm{KH}_{2} \mathrm{PO}_{4} 1.2, \mathrm{NaHCO}_{3} 25, \mathrm{CaCl}_{2} 2.4, \mathrm{MgSO}_{4}$ 1.2 , glucose 10. Cumulative dose-response curves for acetylcholine (Ach) $(0.1-10 \mu \mathrm{M})$ were performed in preparations preconstricted with noradrenaline (NA). The maximal force of contraction induced by NA was taken as $100 \%$ and the relaxation induced by Ach was referred to this value.

Cell line and culture conditions. The coronary venular endothelial cells (CVEC) were obtained by a bead-perfusion technique through the coronary sinus as previously reported (23). These cells are endothelial in nature as evidenced by labeling with antibody to Factor VIII-related antigen and uptake of acetylated low-density lipoproteins. At confluence, they form a typical contact-inhibited monolayer with the usual cobblestone morphology. Cells were maintained in culture in DME supplemented with $2 \mathrm{mM}$ sodium pyruvate, $2 \mathrm{mM}$ L-glutamine, $100 \mu \mathrm{g} / \mathrm{ml}$ heparin, antibiotics ( $100 \mathrm{U} / \mathrm{ml}$ penicillin, $100 \mu \mathrm{g} / \mathrm{ml}$ streptomycin, 0.25 $\mu \mathrm{g} / \mathrm{ml}$ amphotericin), and $20 \%$ FCS on gelatin coated dishes. Cells were cloned and each clone was subcultured up to a maximum of 25 passages. Passages between 15 and 20 were used in these experiments.

$\left[{ }^{3}\right.$ HJThymidine incorporation. DNA synthesis was quantified by $\left[{ }^{3} \mathrm{H}\right]$ thymidine incorporation of subconfluent cell monolayers (14). CVEC were seeded onto 24 multi-well plates $\left(1 \times 10^{4}\right.$ cells/well $)$ in DME supplemented with 5\% FCS and were let to adhere overnight. After $48 \mathrm{~h}$ in serum-free media (0.1\% FCS), media was removed and cells were incubated with increasing concentrations of the agents for 4 , $24,48 \mathrm{~h}$, and $5 \mathrm{~d}$ and pulsed for $1 \mathrm{~h}$ with $0.5 \mu \mathrm{Ci}\left[{ }^{3} \mathrm{H}\right]$ thymidine per well. DNA was precipitated with $5 \%$ TCA and extracted with $0.3 \mathrm{M}$ $\mathrm{NaOH}$ and the recovered radioactivity measured. Data are expressed as recovered $\mathrm{cpm} /$ well or as the percent thymidine incorporation over basal. As a reference for optimal growth condition in each experiment the proliferative effect of $10 \mathrm{ng} / \mathrm{ml} \mathrm{bFGF}$ was used. In experiments where $\mathrm{N}^{\omega}$-mono-methyl-L-arginine (L-NMMA), $\mathrm{N}^{\omega}$-nitro-L-arginine $(\mathrm{L}$ NNA) and L-NAME, and methylene blue (MeB) were used to inhibit NO synthase and guanylate cyclase (23), the drug used was added $1 \mathrm{~h}$ before the agonist.

Proliferation studies. For the proliferation studies, the same protocol as for $\left[{ }^{3} \mathrm{H}\right]$ thymidine incorporation was followed. At the end of each incubation time the supernatants were removed from the multi-well plates and cells were fixed by adding $1 \mathrm{ml}$ of ice-cold methanol and kept at $4^{\circ} \mathrm{C}$ overnight. Cells were then stained with Diff-Quik. Cell numbers were obtained by counting by microscopic examination at $10 \times$ with the aid of an ocular grid $\left(21 \mathrm{~mm}^{2}\right)$. Each well was divided in 10 fields and cells were counted by double blind procedure in seven randomly selected fields. The total cell number/well was calculated by the formula: $m \times R \times I$, where $m$ is the mean cell number/field, $R$ is the ratio between the area of the well and the area of the ocular grid, and I is the magnification used. Values are expressed as total cell number/ well.

Migration assay. The Boyden Chamber procedure was used to evaluate cell migration (17). The method is based on the passage of endothelial cells across porous filters against a concentration gradient of the migration effector. The Neuro Probe 48-well micro-chemotaxis chamber (Nuclepore Corp., Pleasanton, CA) was used. The two wells were separated by a polyvinyl-pyrrolidone (PVP)-free polycarbonate filter, $8 \mu \mathrm{m}$ pore size, coated with type I collagen and fibronectin. Test solutions were dissolved in DME $+1 \%$ FCS and placed in the lower wells. 50 $\mu \mathrm{l}$ of cell suspension $\left(2.5 \times 10^{4}\right.$ cells $)$ was added to each upper well. In the experiments with NO synthase inhibitors, cell suspension was incubated with the inhibitors at $37^{\circ} \mathrm{C}$ for $30 \mathrm{~min}$ before the seeding. The chamber was incubated at $37^{\circ} \mathrm{C}$ for $4 \mathrm{~h}$ and the filter was then removed and fixed in methanol overnight. Nonmigrating cells on the upper surface of the filter were removed with a cotton swab. Cells were stained with Diff-Quik and counted using a light microscope $(40 \times)$ in 

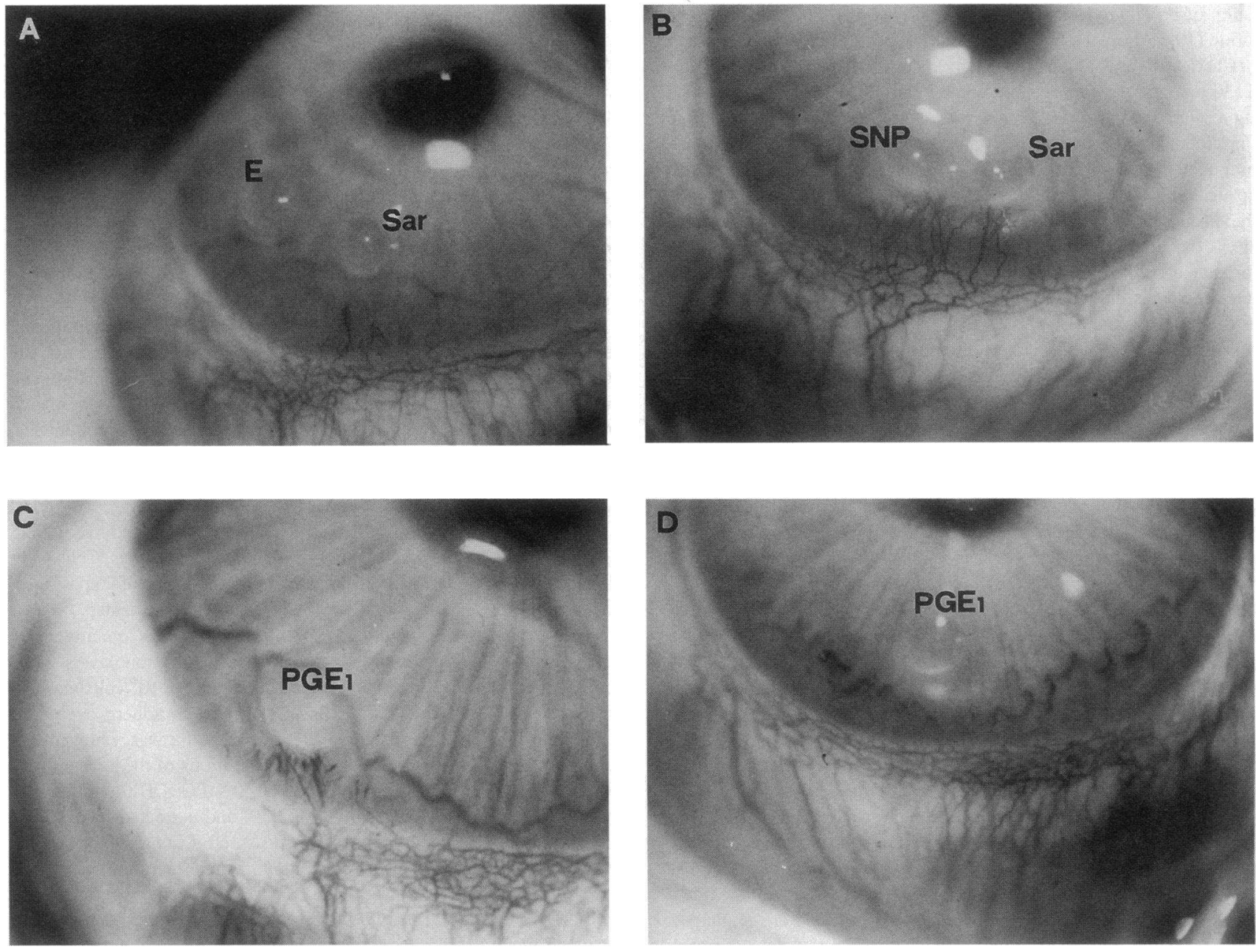

Figure 1. Effect of nitric oxide in corneal angiogenesis. The effect of NO donor SNP on angiogenesis was evaluated by implanting two adjacent pellets in the same cornea, one bearing the angiogenic trigger and the other the NO donor SNP or control. (A) Corneal implant of [Sar ${ }^{9}$ ]-SP-sulfone $0.5 \mu \mathrm{g} /$ pellet (Sar) induced the growth of few slowly progressing capillaries from the pre-existing limbal vessels. Elvax pellet $(E)$ implanted in a parallel pocket was used as control and did not elicit angiogenesis. $(B)$ When the NO-donor drug SNP ( $1 \mu \mathrm{g})$ was present in the adjacent pocket, the angiogenic response elicited by $0.5 \mu \mathrm{g} /$ pellet [Sar $\left.{ }^{9}\right]-S P$-sulfone appeared potentiated in terms of vessel number and growth rate. The effect of NO synthase inhibition was evaluated on angiogenesis produced by PGE $_{1}$. L-NAME or the inactive enantiomer D-NAME were given in the drinking water ad libitum $(0.5 \mathrm{~g} / \mathrm{l}) 1 \mathrm{wk}$ before surgery and $10 \mathrm{~d}$ after corneal implant. $(C)$ Angiogenic response elicited by PGE $10.25 \mu \mathrm{g} / \mathrm{pellet}$ in control conditions and $(D)$ after L-NAME treatment. All pictures $(\times 18)$ were taken at day 8 after surgical implant through a slit stereomicroscope (Nikon, Tokyo, Japan).

10 random fields per each well. Mobilization was measured by the number of cells moving across the filter. Each experimental point was done in triplicate. Mean values of migrated cells for each experimental point were calculated. Migration has been expressed as the mean \pm SEM of the number of total cells counted per experiment.

Determination of NO synthase activity. CVEC were seeded in 100$\mathrm{mm}$ culture dishes and allowed to grow to $90 \%$ confluence. Cells were treated for $24 \mathrm{~h}$ with test substances in DME plus $1 \%$ FCS. At the end of incubation, cells were washed and scraped in Dulbecco's PBS. Samples were kept at $-20^{\circ} \mathrm{C}$ until use. Cells were homogenized in buffer containing $0.32 \mathrm{M}$ sucrose, $20 \mathrm{mM}$ Hepes buffer, $1 \mathrm{mM}$ EDTA, and 1 $\mathrm{mM}$ DTT and centrifuged at $39,000 \mathrm{~g}$ for $30 \mathrm{~min}$. The NO synthase activity was then assayed using $340 \mu \mathrm{l}$ of the supernatant, which was incubated with $60 \mu \mathrm{l}$ of an incubation medium of the following composition: $2 \mathrm{mM} \mathrm{NADPH}^{+}, 0.45 \mathrm{mM} \mathrm{CaCl} 2,10 \mu \mathrm{M}$ calmodulin, $200 \mathrm{mM}$ arginine, ${ }^{3} \mathrm{H}$-L-arginine $(5 \mu \mathrm{Ci} / \mathrm{ml})$ in a total volume of $400 \mu \mathrm{l}$. After $60 \mathrm{~min}$ of incubation at $37^{\circ} \mathrm{C}$ the mixture was loaded on $1 \mathrm{ml}$ Dowex AG50WX-8 ( $\mathrm{Na}^{+}$form) column and eluted by $5 \mathrm{ml}$ of bidistilled water. $\left[{ }^{3} \mathrm{H}\right]$ Citrulline obtained by this procedure was measured by a $\beta$ counter and the ratio between labeled citrulline ( $\mathrm{dpm})$ and $\mathrm{mg}$ protein assayed in the homogenate was taken as NO synthase activity (24). To verify whether $\mathrm{Ca}^{2+}$ concentration could affect changes of NO synthase activity, CVEC homogenates were also resuspended in $\mathrm{Ca}^{2+}$ free buffer containing $1 \mathrm{mM}$ EGTA. Furthermore, the calmodulin inhibitor trifluoperazine $(100 \mu \mathrm{M})$ was used to evaluate the calmodulin-independent NO synthase.

Statistical analysis. The data are reported as means \pm SEM of experiments. Statistical analysis was performed by using one-way analysis of variance followed by Sheffe's test and by Student's $t$ test for paired and/or unpaired data. A $P$ value $<0.05$ was taken as significant.

Materials. All reagents for cell culture were from GIBCO, UK. FCS was from Hyclone (Logan, UT). Diff-Quik was from Mertz-Dade AG (Dudingen, Switzerland). Substance $\mathrm{P}$ and $\left[\mathrm{Sar}^{\mathrm{9}}\right]$-SP-sulfone were from Peninsula Laboratories (Merseyside, UK). SNP, isosorbide dinitrate (ISDN), and glyceryl trinitrate (GTN) were used as NO donors. GTN ( $1 \%$ solution) was from Merck (Bracco, Milan, Italy). SNP and ISDN, NO synthase inhibitors L-NMMA and L-NNA, MeB, L- and D-arginine, $\mathrm{PGE}_{1}$, indomethacin, thrombin, tri- $n$-octylamine, $1,1,2$ trichloro-trifluo- 


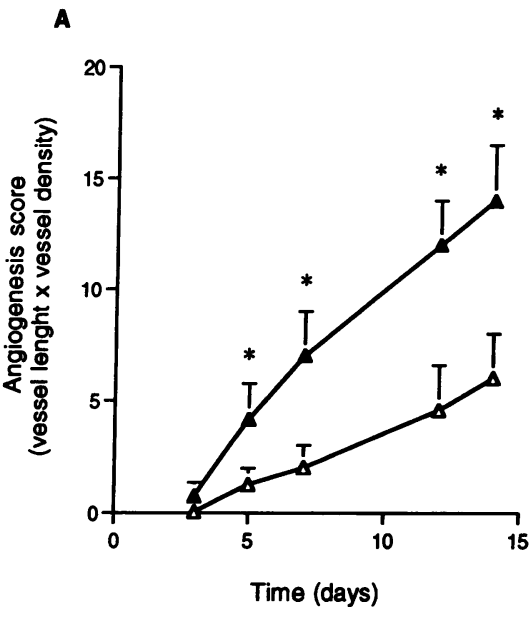

B

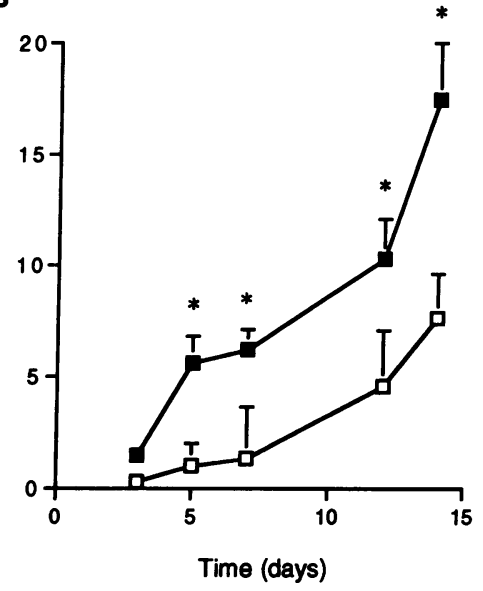

Figure 2. Effect of SNP on corneal angiogenesis promoted by $\mathrm{PGE}_{1}$ and $\left[\mathrm{Sar}^{9}\right]-\mathrm{SP}$-sulfone. $(A) \mathrm{A}$ pellet of $1 \mu \mathrm{g}$ SNP was implanted parallel to a second pellet of [ $\left.\mathrm{Sar}^{9}\right]$-SP-sulfone $(0.5 \mu \mathrm{g} / \mathrm{pellet})$ $(\Lambda)$; the opposite eye of the same rabbit received a corneal implant of [Sar']-SP-sulfone and control pellet $(\Delta)$. $(B)$ Pellets of $\mathrm{PGE}_{1}(0.1 \mu \mathrm{g} /$ pellet $)$ were tested in the presence of a control pellet ( $\square$ ) and in the presence of a SNP-containing pellet (घ). Angiogenesis score was calculated on the basis of the number of vessels and their growth rate versus time (days). The data shown are means \pm SEM obtained from six rabbits. ${ }^{*} P$ $<0.05$ vs [Sar $\left.{ }^{9}\right]-S P$-sulfone or $\mathrm{PGE}_{1}$ alone, Student' $t$ test for paired data. roethane, trifluoperazine, EDTA, EGTA, NADPH ${ }^{+}$, calmodulin, DTT, Ach, NA, type I collagen, and fibronectin were purchased from Sigma Chemical Co. (St. Louis, MO). L-NAME and D-NAME were from Calbiochem (Inalco, Milan, Italy). Fresh solutions of each reagent were prepared before each experiment as $10 \mathrm{mM}$ solution in PBS and diluted in DME containing $0.1 \%$ FCS to final concentration. $\left[{ }^{3} \mathrm{H}\right]$ Thymidine, $\left[{ }^{3} \mathrm{H}\right]$ citrulline, and radio-immunoassay kit for cyclic GMP measurement were from Amersham (Buckinghamshire, UK). 48-well micro-chemotaxis chamber and PVP-free polycarbonate filters were from Nuclepore Corp. Elvax-40 was from Dupont (Wilmington, DE). Sodium pentothal was from Abbott (Latina, Italy). Recombinant bFGF was kindly given by Dr. N. Mongelli (Farmitalia-Carlo Erba, Milan, Italy).

\section{Results}

Effect of sodium nitroprusside on in vivo angiogenesis. To verify the role of NO production in modulating angiogenesis in vivo, we tested the ability of SNP to potentiate the angiogenesis elicited by $\mathrm{PGE}_{1}$ and by [Sar $\left.{ }^{9}\right]-\mathrm{SP}$-sulfone. The selective $\mathrm{NK}_{1}$ receptor agonist, $\left[\mathrm{Sar}^{9}\right]-\mathrm{SP}$-sulfone, was used to rule out a possible effect of the natural tachykinin SP on other tachykinin receptors (20). $\mathrm{PGE}_{1}$ produces a dose-dependent angiogenesis response and is essentially devoid of inflammatory activity in the dose range used $(3,18)$. To study potentiation, threshold doses of $\mathrm{PGE}_{1}(0.1 \mu \mathrm{g})$ or [ $\left.\mathrm{Sar}^{9}\right]-\mathrm{SP}$-sulfone $(0.5 \mu \mathrm{g})$ were tested in the presence and in the absence of the NO-donor SNP. Two adjacent pockets were produced in the same cornea of each rabbit, one bearing the angiogenic trigger and the other SNP or the vehicle.

Rabbit corneas exposed to either [Sar $\left.{ }^{9}\right]-S P$-sulfone or $\mathrm{PGE}_{1}$ in the absence of SNP, produced corneal vascularization in $50 \%$ of the implants ( 3 positive implants out of 6 , and 4 out of 8 , respectively). The angiogenic response was moderate since the vascular buds were delayed as time of appearance, producing sparse new capillaries with a slow growth rate (Fig. $1 A$ ). When SNP $(1 \mu \mathrm{g})$ was released into the corneal stroma simultaneously with $\mathrm{PGE}_{1}$ or $\left[\mathrm{Sar}^{9}\right]-\mathrm{SP}$-sulfone, a sharp improvement in the efficiency of the angiogenesis response was observed (Fig. 1 $B$ ). The number of implants exhibiting positive angiogenesis was 5 out of 6 and 6 out of 6 for [Sar $\left.{ }^{9}\right]-S P$-sulfone and for $\mathrm{PGE}_{1}$, respectively. The intensity of the angiogenic response, quantified by the number of new vessels and their growth rate, was potentiated during each observation (Fig. 2, $A$ and $B$ ). SNP alone $(1 \mu \mathrm{g} /$ pellet) elicited in $30 \%$ of the implants the budding of few capillaries which regressed after $4 \mathrm{~d}$ from surgery. A higher concentration ( $5 \mu \mathrm{g} /$ pellet) of SNP produced an inflammatory response visualized by the appearance of corneal opacity.

Effect of systemic L-NAME treatment on angiogenesis in vivo. The relevance of endogenous NO production to the angiogenesis process was tested by systemic administration of the NO synthase inhibitor L-NAME (21). The angiogenic response after corneal implants of $\mathrm{PGE}_{1} 0.25 \mu \mathrm{g} /$ pellet and [Sar $\left.{ }^{9}\right]-\mathrm{SP}$ sulfone $1 \mu \mathrm{g} /$ pellet is reported in Fig. $1 C$. When rabbits were fed in the drinking water with L-NAME $(0.5 \mathrm{~g} / \mathrm{l})$ for $1 \mathrm{wk}$ before surgery, angiogenesis was drastically reduced (Table I, Fig. $1 D$ ). Conversely, treatment with the inactive enantiomer D-NAME or with a lower concentration of L-NAME $(0.1 \mathrm{~g} / \mathrm{l})$ did not modify the angiogenic response to either stimuli. When animals receiving chronic L-NAME treatment were returned to normal diet, the corneal implants of $\mathrm{PGE}_{1}$ and [Sar']-SP-sulfone produced angiogenesis as in control untreated rabbits ( 3 positive implants out of 3 and 2 positive implants out of 3 , respectively). The angiogenic response induced by bFGF $(0.1 \mu \mathrm{g} /$ pellet $)$ and measured at day 10 after pellet implantation, was not abolished by systemic treatment with L-NAME $(0.5 \mathrm{~g} / \mathrm{l})$.

Table I. Angiogenesis in Rabbit Cornea during Treatment with Nitric Oxide Synthase Inhibitor

\begin{tabular}{lccc}
\hline & & \multicolumn{2}{c}{ Treatment } \\
\cline { 3 - 4 } $\begin{array}{c}\text { Pellet implant } \\
(\mu \text { g/pellet })\end{array}$ & Control & L-NAME & D-NAME \\
\hline Elvax & $0 / 6$ & $0 / 6$ & $0 / 6$ \\
PGE $_{1}(0.25)$ & $5 / 6$ & $0 / 6$ & $5 / 6$ \\
Elvax & $0 / 6$ & $0 / 6$ & $0 / 6$ \\
[Sar']-SP (1) & $4 / 6$ & $0 / 6$ & $5 / 6$ \\
Elvax & $0 / 5$ & $0 / 5$ & - \\
bFGF (0.1) & $4 / 5$ & $3 / 5$ & - \\
\hline
\end{tabular}

L-NAME and D-NAME treatments were given in the drinking water ad libitum. Drug solutions $(0.5 \mathrm{~g} / \mathrm{l})$ were prepared fresh every day. Animal water intake was $\sim 200 \mathrm{ml} / \mathrm{d}$ and was not different from control animals. Animals were kept under treatment 1 wk before performing surgery and $10 \mathrm{~d}$ after corneal implant. Results represent the observation obtained at day 7 after surgery. Data are expressed as positive angiogenic implants over total implants. 
Table II. Vasorelaxant Effect Induced by Ach in Aortic Rings

\begin{tabular}{lccc}
\hline & \multicolumn{3}{c}{ Treatment } \\
\cline { 2 - 4 } Compound & None & L-NAME & D-NAME \\
\hline & & $\%$ vasorelaxation \\
Ach & & & \\
$0.1 \mu \mathrm{M}$ & $22.2 \pm 3.4$ & $2.0 \pm 0.6^{* \ddagger}$ & $20.6 \pm 2.2$ \\
$1.0 \mu \mathrm{M}$ & $59.7 \pm 3.6$ & $9.9 \pm 1.9^{* \ddagger}$ & $52.3 \pm 3.1$ \\
$10 \mu \mathrm{M}$ & $67.9 \pm 4.1$ & $10.3 \pm 2.2^{* \ddagger}$ & $57.1 \pm 3.7$
\end{tabular}

The vasorelaxation induced by Ach was evaluated in aortic rings isolated from rabbits receiving chronic treatments $(0.5 \mathrm{~g} / \mathrm{l})$ for $18 \mathrm{~d}$. The vasoconstrictor response induced by NA was taken as $100 \%$ and the effect of Ach was referred to this value. Data are the results of 10 aortic rings for each group. ${ }^{*} P<0.01$ vs control and ${ }^{\ddagger}$ vs D-NAME-treated rabbits (analysis of variance, Scheffe's test).

Effect of NO synthase inhibition on thrombin-stimulated aggregation and cyclic GMP levels in rabbit platelets. The efficacy of systemic L-NAME treatment in reducing endogenous NO production was tested on aggregation and cyclic GMP levels in platelets obtained from the same rabbits at 10 and $18 \mathrm{~d}$ after the beginning of treatment. In animals receiving $0.5 \mathrm{~g} / \mathrm{l}$ L-NAME for $10 \mathrm{~d}$, platelet aggregation was increased up to $159 \%$ of controls. Similar increase was observed at day 18. Cyclic GMP levels in platelets obtained from the untreated animals were $0.65 \pm 0.12 \mathrm{fmol} / \mu \mathrm{g}$ protein; in animals receiving L-NAME cyclic GMP levels were significantly reduced as compared to controls and to animals treated with D-NAME $(0.37 \pm 0.07$ and $0.94 \pm 0.09 \mathrm{fmol} / \mu \mathrm{g}$ protein for L-NAME and D-NAME, respectively, $n=4, P<0.01$ ). The reduction of cyclic GMP levels was maintained at the same extent at day 18 and returned to control values after discontinuation of treatment. In animals receiving $0.1 \mathrm{~g} / \mathrm{l}$ of L-NAME platelet aggregation was increased to $64 \%$ compared with controls, while cyclic GMP levels were not significantly reduced $(0.84 \pm 0.21 \mathrm{fmol} /$ $\mu \mathrm{g}$ protein for L-NAME versus $1.36 \pm 0.55$ in D-NAME and $0.93 \pm 0.37$ in controls).

Effect of NO synthase inhibition on the vasorelaxant response of rabbit aorta. The vasorelaxant responses to Ach were measured in aortic rings preconstricted with NA obtained from animals receiving chronic treatment with L-NAME or D-NAME (Table II). Ach $(0.1-10 \mu \mathrm{M})$ induced a dose-dependent relaxation in preparations obtained from control and D-NAME treated animals, which was significantly reduced in aortic rings from L-NAME-treated animals. Ach-vasorelaxant response reverted to control in aortic rings obtained from animals returned to normal diet.

Effect of sodium nitroprusside on cell growth. Exposure of serum-deprived subconfluent monolayers of CVEC to SNP induced the activation of DNA synthesis, as detected by $\left[{ }^{3} \mathrm{H}\right]-$ thymidine incorporation. At $24 \mathrm{~h}$, the recovered radioactivity increased by $55 \%$ over basal values in the presence of $100 \mu \mathrm{M}$ SNP. After $5 \mathrm{~d}$ of exposure to SNP, thymidine incorporation of treated cells was still higher (54\% increase) as compared with control condition (Fig. $3 \mathrm{~A}$ ). As a positive control for cell growth, the cells were challenged with the recombinant peptide growth factor bFGF $(10 \mathrm{ng} / \mathrm{ml})$ at each time point. The extent of SNP-induced DNA synthesis was similar to that obtained with bFGF.

The increase in thymidine incorporation promoted by SNP was paralleled by a concentration-dependent increment of the total cell number (Fig. $3 \mathrm{~B}$ ). The maximal effect was observed with $100 \mu \mathrm{M}$ SNP (38 and 53\% increment at 2 and $5 \mathrm{~d}$, respectively). The increment in cell number obtained at $5 \mathrm{~d}$ with bFGF was $72 \%$ over basal values.

Effect of NO synthase inhibition on stimulation of DNA synthesis and cyclic GMP production induced by SP. To assess the role played by NO production in mediating the proliferative effect of SP, we evaluated the activity of NO synthase inhibitors on thymidine incorporation in CVEC exposed to increasing concentrations of SP. Subconfluent monolayers of CVEC were treated for $1 \mathrm{~h}$, before SP exposure, with $100 \mu \mathrm{M}$ L-NMMA, L-NAME, and L-NNA (21). NO synthase inhibitors did not
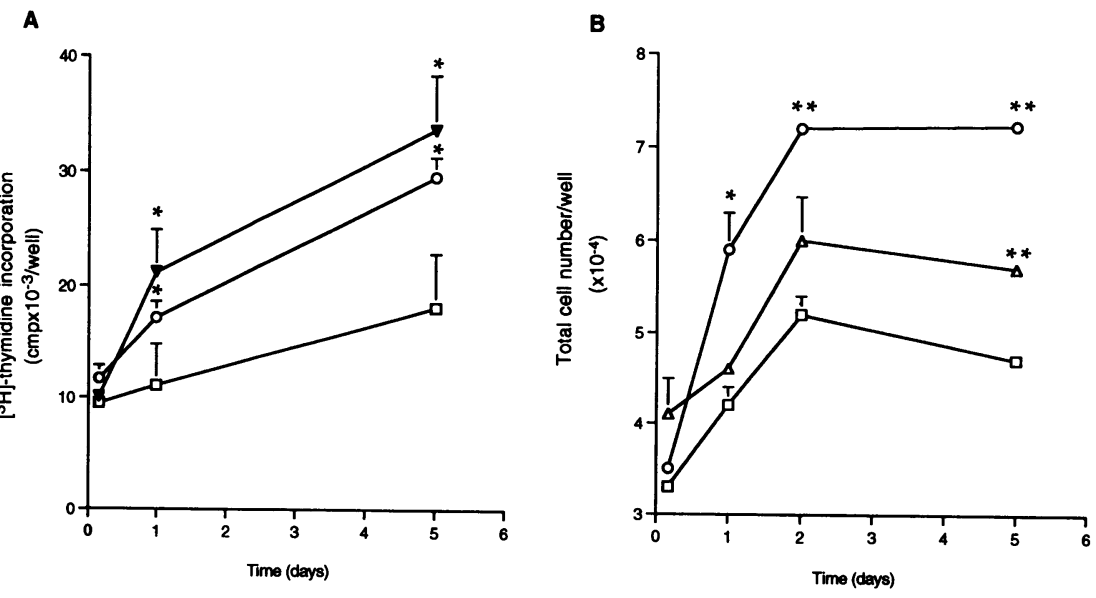

Figure 3. Proliferative effect of SNP on CVEC DNA synthesis $(A)$ and proliferation $(B) .(A)$ Thymidine incorporation was monitored after exposure to SNP. CVEC were seeded onto 24 multi-well plates $\left(1 \times 10^{4}\right.$ cells/well $)$ and starved for $48 \mathrm{~h}$ in serum-free media ( $0.1 \%$ FCS). Cells were incubated with $100 \mu \mathrm{M} \mathrm{SNP}(0)$ for 4,24 $\mathrm{h}$, and $5 \mathrm{~d}$ and pulsed with $0.5 \mu \mathrm{Ci}\left[{ }^{3} \mathrm{H}\right]$ thymidine per well. DNA was precipitated, extracted, and the recovered radioactivity measured. Data are expressed as recovered cpm per well. As a reference for optimal growth condition in each experiment the proliferative effect of $10 \mathrm{ng} / \mathrm{ml} \mathrm{bFGF}$ (ム) was used. The open squares represent basal proliferation in the presence of $0.1 \%$ FCS. Data are representative of six experiments run in duplicate. ${ }^{*} P<0.05$ vs basal, Student' $t$ test.

(B) Total cell number after exposure to SNP. At the end of each incubation time ( $24 \mathrm{~h}, 48 \mathrm{~h}$, and $5 \mathrm{~d}$ ) cells were fixed with methanol and stained with Diff-Quik. Cell numbers were obtained by counting by microscopic examination at $10 \times$ with the aid of an ocular grid $\left(21 \mathrm{~mm}^{2}\right)$. Each well was divided in 10 fields and cells were counted by double blind procedure in 7 randomly selected fields. The total cell number/well was calculated by the formula: $\mathrm{m} \times \mathrm{R} \times \mathrm{I}$, where $\mathrm{m}$ is the mean cell number/field, $R$ is the ratio between the area of the well and the area of the ocular grid, and $I$ is the magnification used. Values are expressed as total cell number/well. Data represent the result of five experiments in duplicate. ( $\triangle$ ) SNP $10 \mu \mathrm{M} ;(0)$ SNP $100 \mu \mathrm{M}$; ( $\square)$ basal $(0.1 \%$ FCS). $* P<0.05$ and ${ }^{* *} P<0.01$ vs basal. 


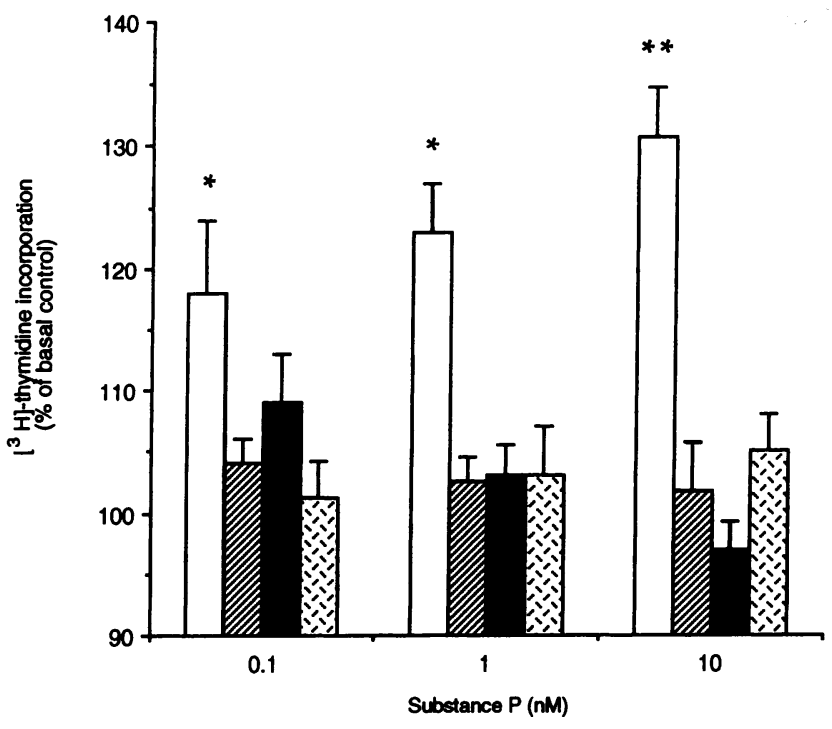

Figure 4. Effect of NO synthase inhibitors on DNA synthesis in CVEC exposed to SP. Cell monolayers were pretreated with $100 \mu \mathrm{M}$ NO synthase inhibitors (L-NMMA [⿴囗十], L-NNA [], and L-NAME [घ]) for $1 \mathrm{~h}$ and then exposed for $24 \mathrm{~h}$ to SP ( $\square$ ). Proliferation was measured by thymidine incorporation. The effect of SP was evaluated over the basal controls (NO synthase inhibitors alone, taken as $100 \%$ ). Data represent the results of four experiments in duplicate. ${ }^{*} P<0.01$ and ${ }^{* *} P<0.001$ vs basal controls, Student's $t$ test.

modify basal DNA synthesis. Thymidine incorporation produced by SP was reduced by L-NMMA, L-NAME, and L-NNA at all concentrations tested (Fig. 4). To assess the specificity of NO synthase inhibition on the reduction of cell growth, cells were also challenged with D-NAME. CVEC treated with DNAME did not modify their proliferative response to $10 \mathrm{nM}$ SP as compared with the untreated control cells $(41.5 \pm 6 \%$ and $34.5 \pm 8 \%$ increment over basal, respectively).

Further support for a role of NO production in mediating the proliferative response evoked by SP was also evidenced by the effect of $\mathrm{MeB}(1 \mu \mathrm{M})$, an inhibitor of guanylate cyclase (21), which abolished the increase of thymidine incorporation elicited by SP at all the concentrations tested (Fig. 5).

Effect of NO-donor drugs on endothelial cell migration. Endothelial cell mobilization at the microvascular level is a prerequisite for the neovascular response to occur in vivo (2). NO generating drugs were tested for their ability to promote in vitro endothelial cell migration. Increasing concentrations of ISDN, GTN, and SNP were used. All drugs induced a concentration-dependent increase of CVEC migration (Fig. 6). Maximal effects were obtained at the following micromolar concentrations: ISDN, $10(207 \pm 7$ migrated cells/well); GTN, 1 (164 \pm 2.3 migrated cells/well); SNP, 100 (171 \pm 3.4 migrated cells/well). Control values were $98 \pm 2$ for the basal condition and 179 \pm 7 migrated cells/well, for bFGF (10 nM) induced migration.

Effect of NO synthase inhibition on SP-induced migration. SP produces a concentration-dependent effect on endothelial cell migration (17). Concentrations producing submaximal (1 $\mathrm{nM})$ and maximal $(10 \mathrm{nM})$ effects were used in these experiments (see Fig. 7). In cells pretreated for $30 \mathrm{~min}$ with $100 \mu \mathrm{M}$ of the NO synthase inhibitors (L-NMMA, L-NNA, or L-NAME)

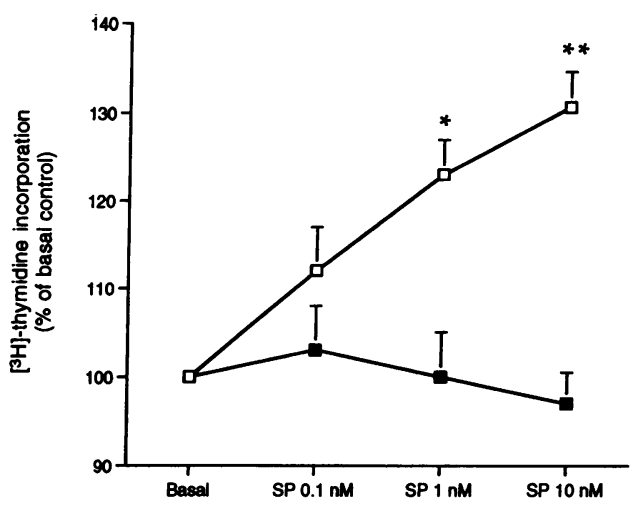

Figure 5. Effect of methylene blue on SP-induced proliferation of CVEC. Inhibition of guanylate cyclase in CVEC monolayers was obtained by $1 \mathrm{~h}$ pretreatment with methylene blue $(1 \mu \mathrm{M})(\square)$. The proliferation induced by SP ( $\square$ ) was measured as thymidine incorporation after $24 \mathrm{~h}$ exposure. The effect of SP was evaluated over the basal controls ( $0.1 \%$ FCS or methylene blue, taken as $100 \%)$. Data represent the result of four experiments in duplicate. ${ }^{*} P<0.01$ and ${ }^{* *} P<0.001$ vs basal controls, Student's $t$ test.

before the exposure to SP, SP-effects were abolished. The effects produced by $10 \mathrm{nM}$ bFGF were not (Fig. 8). Inhibition of SP-induced migration by blockade of NO synthase was specific since D-NAME was ineffective (Fig. $9 A$ ), and the effect of LNMMA was reverted by addition of $\mathrm{L}$-arginine $(200 \mu \mathrm{M})$ (Fig. 9 B).

Effects of SP on NO synthase activity in CVEC. Subconfluent monolayers of CVEC were analyzed for NO synthase activity after $24 \mathrm{~h}$ exposure to $10 \mathrm{nM} \mathrm{SP}$, a concentration known to produce maximal biological response in capillary endothelial cells $(15,17)$. In resting conditions the activities of calciumdependent and calcium-independent isoforms of NO synthase

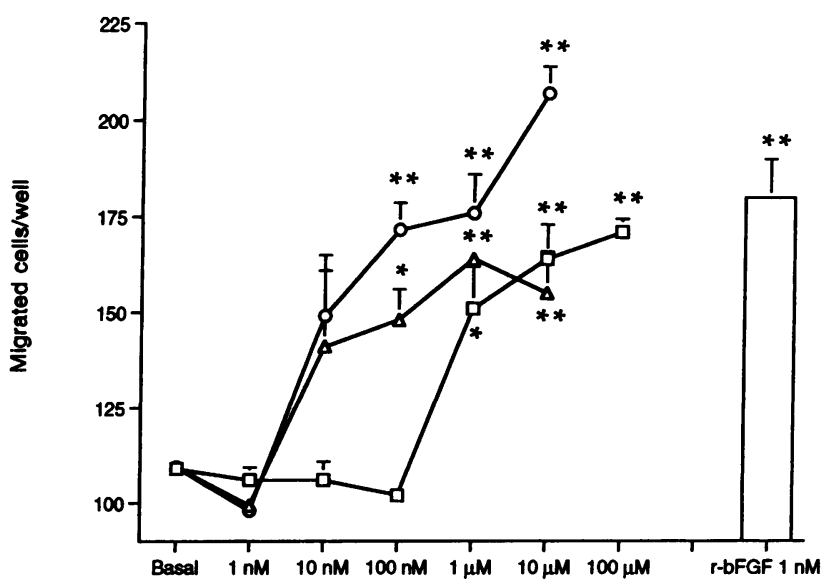

Figure 6. Effect of NO generator drugs on CVEC mobilization. For migration assay, 48-well modified Boyden Chambers were used, as described in Methods. The NO-donor drugs (ISDN [O], TNG[ $\Delta$ ], and SP [ $\square]$ ]) in DME containing 0.1\% FCS, were seeded in the lower compartments of the chamber and endothelial cell suspension was seeded in the upper compartments. Cells migrated after $4 \mathrm{~h}$ of incubation to the lower surface of the filter were counted. bFGF (10 nM) (open column) was used as positive control. Data are the means \pm SEM of three experiments run in triplicate. ${ }^{*} P<0.01$ and ${ }^{* *} P<0.001$ vs basal mobilization, Student' $t$ test. 


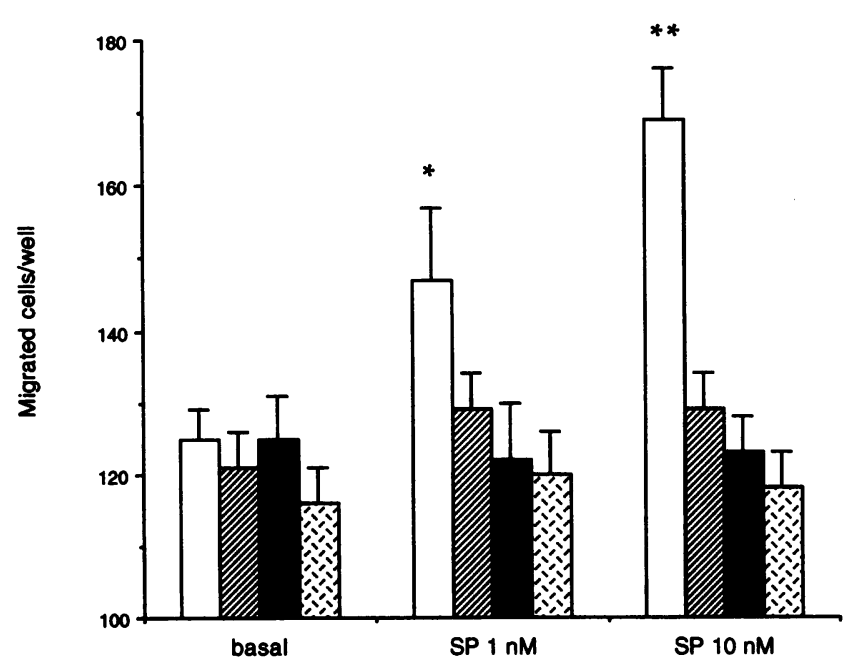

Figure 7. Effect of NO synthase inhibitors on SP-induced mobilization of CVEC. SP-induced mobilization ( $\square$ ) was studied in cells preincubated for 30 min with NO synthase inhibitors (L-NMMA [ L-NNA [ $[$ ], and L-NAME [छ], $100 \mu \mathrm{M}$ ). Data are the results of five experiments run in triplicate. ${ }^{*} P<0.01$ and ${ }^{* *} P<0.001$ vs control, Student's $t$ test.

were detected. In cells exposed to $10 \mathrm{nM}$ SP the activities of both isoforms were increased compared with basal values (Fig. 10). In the presence of calcium, the NO synthase activity in CVEC stimulated with SP increased by $351 \%$. When the cell homogenates were resuspended in $\mathrm{Ca}^{2+}$-free buffer (EGTA 1 $\mathrm{mM})$ and in the presence of the calmodulin inhibitor trifluoperazine $(100 \mu \mathrm{M})$, the NO synthase activity increased slightly but

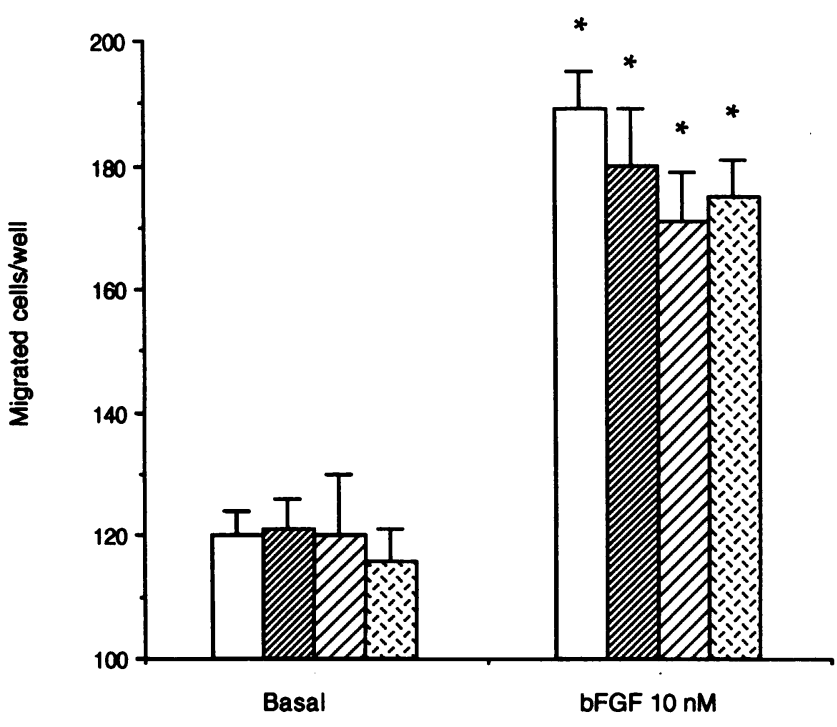

Figure 8. Effect of NO synthase inhibitors on bFGF-induced mobilization of CVEC. Cell mobilization was produced with $10 \mathrm{nM}$ bFGF (ㅁ). The effect of cell preincubated for $30 \mathrm{~min}$ with the NO synthase inhibitors L-NAME ( $(\mathbb{)})$ and L-NNA $(\nabla)(100 \mu \mathrm{M})$ was evaluated and compared to the effect of the inactive enantiomer D-NAME (ब) (100 $\mu \mathrm{M})$. Data are the results of three experiments run in triplicate. ${ }^{*} P$ $<0.01$ vs control, Student's $t$ test.
A
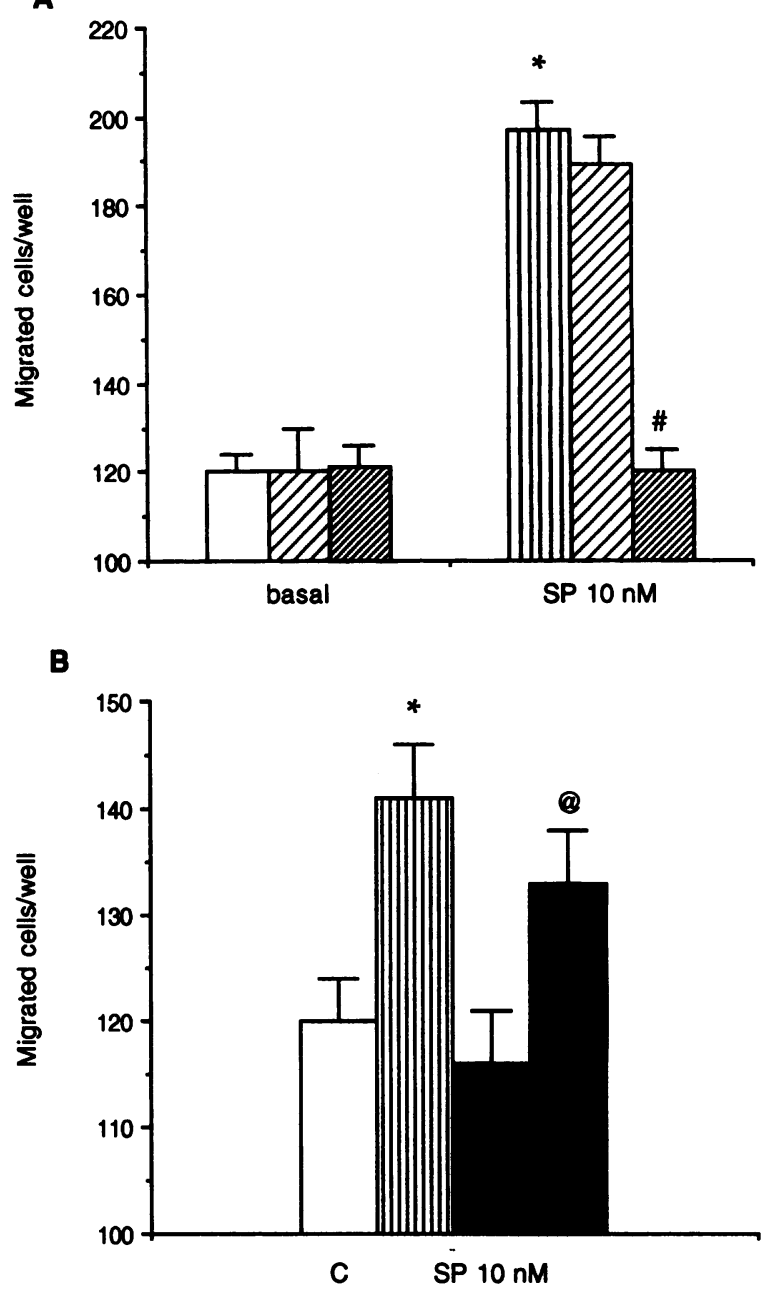

Figure 9. SP-induced mobilization of CVEC after treatment with LNAME and D-NAME $(A)$ and L-NMMA and L-arginine $(B)$. $(A)$ To evaluate the specificity of NO synthase inhibition produced by $\mathrm{L}$ NAME, the effect of the inactive enantiomer D-NAME was studied on mobilization of CVEC induced by SP. Cells were preincubated for 30 min with $100 \mu \mathrm{M}$ of each drug. Data are the result of three experiments run in triplicate. ${ }^{*} P<0.01$ vs basal migration and $P<0.01$ vs 10

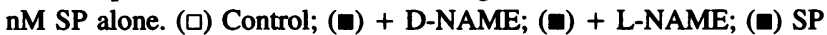
alone. $(B)$ The effect of $L$-arginine in reverting the inhibitory effect produced by L-NMMA was evaluated on SP-induced mobilization. Cells were incubated for $30 \mathrm{~min}$ with media containing L-arginine $(200 \mu \mathrm{M})$ and L-NMMA $(100 \mu \mathrm{M})$. Then cell migration was evaluated versus 10 nM SP. Data are the results of three experiments run in triplicate. $* P$ $<0.05$ vs basal migration and ${ }^{\oplus} P<0.05$ vs L-NMMA alone. ( $\square$ ) Control; (匹) SP, 10 nM; (घ) SP + L-NMMA; (匹) SP + L-NMMA + L-Arg.

the effect was not statistically significant. These results show that SP activated mainly a calcium- and calmodulin-dependent NO synthase.

\section{Discussion}

The present data suggest that neovascular response in vivo and some cellular events relevant for angiogenesis, such as the growth and mobilization of postcapillary venule endothelial cells, are promoted by NO. We show that SNP potentiates neo- 


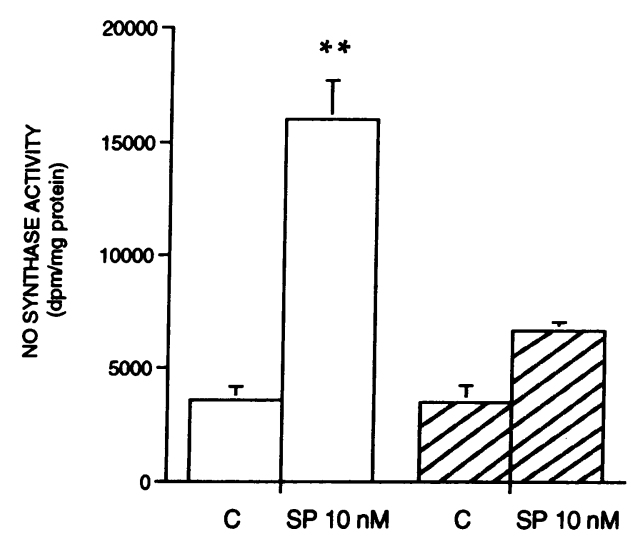

Figure 10. NO synthase activity in CVEC exposed to SP. Monolayers of CVEC at $95 \%$ confluence were exposed to $10 \mathrm{nM}$ SP for $24 \mathrm{~h}$. At the end of incubation, cells were washed and scraped in PBS, homogenized and centrifuged at $39,000 \mathrm{~g}$ for $30 \mathrm{~min}$. The calcium-dependent NO synthase activity was measured in the supernatant of cell extracts incubated for $60 \mathrm{~min}$ at $37^{\circ} \mathrm{C}$ with medium containing $\mathrm{NADPH}^{+}, \mathrm{CaCl}_{2}$, calmodulin, cold L-arginine, and ${ }^{3} \mathrm{H}-\mathrm{L}$-arginine $(5 \mu \mathrm{Ci} / \mathrm{ml})(\square)$. The calcium- and calmodulin-independent NO synthase activity ( $\square$ ) was measured in the supernatant with the calcium-free media containing $1 \mathrm{mM}$ EGTA and $100 \mu \mathrm{M}$ trifluoperazine. The mixtures were then loaded on Dowex AG50WX-8 ( $\mathrm{Na}^{+}$form) column and eluted with bidistilled water. The $\left[{ }^{3} \mathrm{H}\right]$ citrulline obtained by this procedure was measured and the ratio between labeled citrulline (dpm) and $\mathrm{mg}$ protein assayed in the homogenate was taken as NO synthase activity. Data are the means \pm SEM of six determinations. ${ }^{* *} P<0.001$ vs basal activity, Student's $t$ test.

vascular response triggered by threshold concentrations of SP and $\mathrm{PGE}_{1}$ in vivo. Different nitrovasodilators, such as SNP, which releases NO spontaneously (25), or GTN and ISDN, which release NO after enzymatic metabolism $(26,27)$, promote growth and mobilization of capillary endothelium in vitro in a dose-dependent fashion (14). We also present evidence that the release of NO mediates endothelial cell proliferation and migration and angiogenesis induced by the vasoactive agent SP, but not by bFGF.

The L-arginine NO pathway was activated in cells exposed to SP. Both isoforms of NO synthase, the calcium-dependent and the calcium-independent (28), are present in resting conditions in the endothelial cells used in this study. SP markedly increased the activity of the calcium-dependent isoform of the enzyme. Moreover, NO synthase inhibitors abolished the proliferation and migration of endothelial cells induced by SP, indicating that endogenous NO production is involved in the cellular effects promoted by this peptide. That NO is specifically involved in the signal transduction following tachykinin receptor activation is further indicated by the observations that the inactive enantiomer D-NAME was ineffective and L-arginine reverted the inhibition induced by L-NAME.

NO exerts its effect by activating a soluble guanylate cyclase (9). In keeping with the hypothesis that NO synthase is stimulated by SP, we found that SP activates cyclic GMP production in CVEC (13). This elevation was significantly reduced by the NO synthase inhibitor L-NMMA, thus indicating that NO production is directly involved (13). A role for guanylate cyclase in mediating the proliferative effect of SP is further suggested by the observation that methylene blue selectively blocked the proliferation of CVEC induced by SP.
Inhibition of NO production caused by chronic systemic administration of L-NAME in vivo strongly curtailed the ability of $\mathrm{SP}$ and $\mathrm{PGE}_{1}$ to elicit the neovascular response. NO-mediated processes (basal cyclic GMP levels in platelets and thrombininduced platelet aggregation, as well as Ach-induced dilation of aortic rings) were inhibited after addition of L-NAME in drinking water, indicating that this treatment provided an effective and long-lasting inhibition of NO production. The impairment of the angiogenic response after NO synthase inhibition is reversible since it was restored after discontinuation of the treatment. These data document that NO production is an essential step for angiogenesis induced by $\mathrm{PGE}_{1}$ and SP.

Angiogenesis relies essentially on the ability of capillary endothelium to migrate and proliferate (2). The extent of proliferation and migration obtained with the NO generating drugs is of the same magnitude as that produced by bFGF. However, NO production does not seem to be involved in the effect of bFGF at cellular level. In fact, inhibition of NO synthase both in vivo and in vitro failed to modify growth and migration of capillary endothelium promoted by bFGF, indicating that more than one pathway contributes to the cellular events leading to angiogenesis (29-31); the prevention of SP- or $\mathrm{PGE}_{1}$-induced angiogenesis by NO synthase inhibitors is consequent to selective blockade of one of these specific effector pathways.

Neovascularization is of relevance during inflammation, wound healing, and tumor growth and the study of these processes has resulted in the identification of a wide variety of angiogenesis inducers $(3,4,15,19)$. The morphogenetic program of the neovascular response requires multiple steps, and an increase in blood flow and vasodilation of the parent venule before the emergence of the first capillary sprouts are important steps $(6,32)$. SP and $\mathrm{PGE}_{1}$ are potent vasodilators, and their effects are mediated, at least in part, by endothelium-dependent vasorelaxation. It is possible that angiogenesis promoted by SP and $\mathrm{PGE}_{1}$, and its inhibition by L-NAME, could rely only on the hemodynamic effect exerted by these agents. Several observations are in contrast with this hypothesis. NO synthase inhibitors blocked mobilization and proliferation of endothelial cells induced by SP in vitro. These findings indicate that on capillary endothelium NO production may trigger events relevant for angiogenesis in a manner independent of hemodynamic changes. Moreover L-NAME did not affect bFGF-induced neovascularization.

The present data do not rule out a role for vasodilation on angiogenesis evoked by SP and NO. However, they suggest that changes in blood flow are not the sole cause of this effect. Since smooth muscle cells are not present at the capillary level, it is possible that other cell types might be the target of NO released from endothelium. Our data suggest that NO production mediates SP effects on capillary endothelium acting in an autocrine way. It is possible to speculate that the production of $\mathrm{NO}$, in response to vasoactive agents such as $\mathrm{SP}$ and $\mathrm{PGE}_{1}$, induces endothelial cells to modify the matrix in which capillaries are embedded, promoting endothelial cell mitogen release (33).

During the completion of this report a paper appeared indicating a role for NO in monocyte-induced angiogenesis (34). In contrast, a previous report had indicated that inhibition of NO synthase in the chorioallantoic membrane of the chick embryo alters the development of microvessel (35). The data obtained by Leibovich et al. (34) as well as our data were obtained 
in adult and highly differentiated cells, a fact that might explain these differences.

Overall, the results obtained in this study provide the first evidence that endothelial NO has a physiological role in the modulation of angiogenesis triggered by vasoactive agents such as SP, acting through autocrine-paracrine mechanisms.

\section{Acknowledgments}

We thank Professor A. Giachetti (Florence, Italy) for advice and criticism in the preparation of the manuscript and Drs. V. Mollace and A. M. Paoletti (Rome, Italy) for their valid collaboration in NO synthase assay.

The work was supported by Associazione Italiana per la Ricerca sul Cancro (AIRC), by Ministero dell'Universita' e della Ricerca Scientifica e Tecnologica (MURST), by Consiglio Nazionale delle Ricerche (CNR), by MERIT award HL-21498 from the National Heart, Lung and Blood Institute, and by a grant from the Texas Advanced Research and Technology Program.

\section{References}

1. Folkman, J. 1982. Angiogenesis: initiation and control. Ann. NY Acad. Sci. 401:212-227.

2. Ausprunk, D. H., and J. Folman. 1977. Migration and proliferation of endothelial cells in preformed and newly formed blood vessels during tumor angiogenesis. Microvasc. Res. 14:53-65.

3. Ziche, M., J. Jones, and P. M. Gullino. 1982. Role of prostaglandin $E_{1}$ and copper in angiogenesis. J. Natl. Cancer Inst. 69:475-482.

4. Meininger, C. J., M. E. Shelling, and H. J. Granger. 1988. Adenosine and hypoxia stimulate proliferation and migration of endothelial cells. Am. J. Physiol. 255:H554-H562.

5. Dusseau, J. W., P. M. Hutchins, and D. S. Malbasa. 1986. Stimulation of angiogenesis by adenosine on chick chorioallantoic membrane. Circ. Res. 59(2):163-170.

6. Ziada, A. M. A. R., O. Hudlicka, K. R. Tyler, and A. J. A. Wright. 1984. The effect of long-term vasodilatation on capillary growth and performance in rabbit heart and skeletal muscle. Cardiovasc. Res. 18:724-732.

7. Ignarro, L. J., G. M. Buga, K. S. Wood, R. E. Byrns, and G. Chaudhuri. 1987. Endothelium-derived relaxing factor produced and released from artery and vein is nitric oxide. Proc. Natl. Acad. Sci. USA. 84:9265-9269.

8. Palmer, R. M. J., A. G. Ferridge, and S. Moncada. 1987. Nitric oxide release accounts for the biological activity of endothelium-derived relaxing factor. Nature (Lond.). 327:524-526.

9. Ignarro, L. J., R. G. Harbinson, K. S. Wood, and P. J. Kadowitz. 1986. Activation of purified guanylate cyclase by endothelium-derived relaxing factor from intrapulmonary artery and vein: stimulation by acetylcholine, bradykinin and arachidonic acid. J. Pharmacol. Exp. Ther. 237:893-900.

10. Lembek, F., and P. Holzer. 1979. Substance $P$ as a neurogenic mediator of antidromic vasodilation and neurogenic plasma extravasation. Naunyn-Schmiedeberg's Arch. Pharmakol. 310:176-183.

11. D'Orleans-Juste, P., S. Dion, J. Mizrahi, and D. Regoli. 1985. Effects of peptides and nonpeptides on isolated arterial smooth muscles: role of endothelium. Eur. J. Pharmacol. 114:9-21.

12. D'Orleans-Juste, P., S. Dion, G. Drapeau, and D. Regoli. 1986. Different receptors are involved in the endothelium-mediated relaxation and the smooth muscle contraction of the rabbit pulmonary artery in response to substance $P$ and related neurokinins. Eur. J. Pharmacol. 125:37-44.

13. Ziche, M., L. Morbidelli, A. Parenti, S. Amerini, H. J. Granger, and C. A.
Maggi. 1993. Substance $P$ increases cyclic GMP levels on coronary postcapillary venular endothelial cells. Life Sci. 53:1105-1112.

14. Ziche, M., L. Morbidelli, E. Masini, H. J. Granger, P. Geppetti, and F. Ledda. 1993. Nitric oxide promotes DNA synthesis and cyclic GMP formation in endothelial cells from postcapillary venules. Biochem. Biophys. Res. Commun. 192:1198-1203.

15. Ziche, M., L. Morbidelli, M. Pacini, P. Geppetti, G. Alessandri, and C. A. Maggi. 1990. Substance P stimulates neovascularization in vivo and proliferation of cultured endothelial cells. Microvasc. Res. 40:264-278.

16. Fan, T.-P., D.-E. Hu, S. Guard, G. A. Gresham, and K. J. Watling. 1993. Stimulation of angiogenesis by substance $P$ and interleukin-1 in the rat and its inhibition by $\mathrm{NK}_{1}$ or interleukin-1 receptor antagonists. Br. J. Pharmacol. 110:4349.

17. Ziche, M., L. Morbidelli, P. Geppetti, C. A. Maggi, and P. Dolara. 1991. Substance $P$ induces migration of capillary endothelial cells: a novel $\mathrm{NK}_{1}$ selective receptor mediated activity. Life Sci. 48:PL7-PL11.

18. Ziche, M., G. Alessandri, and P. M. Gullino. 1989. Gangliosides promote the angiogenic response. Lab. Invest. 61:629-634.

19. Gullino, P. M. 1981. Angiogenic factor(s). In Handbook of Experimental Pharmacology. Springer-Verlag. Berlin. 57:427-449.

20. Regoli, D., G. Drapeau, S. Dion, and R. Couture. 1988. New selective agonists for neurokinin receptors: pharmacological tools for receptor characterization. TIPS (Trends Pharmacol. Sci.) 9:290-295.

21. Moncada, S., R. M. J. Palmer, and E. A. Higgs. 1991. Nitric oxide: physiology, pathophysiology and pharmacology. Pharmacol. Rev. 43:109-142.

22. Radomsky, M. W., and S. Moncada. 1983. An improved method for washing human platelets with prostacyclin. Thromb. Res. 30:383-389.

23. Schelling, M. E., C. J. Meininger, J. R. Hawker, and H. J. Granger. 1988. Venular endothelial cells from bovine heart. Am. J. Physiol. 254:H1211-H1217.

24. Mollace, V., M. Colasanti, P. Rodino', R. Massoud, G. M. Lauro, and G. Nistico'. 1993. Cytokine-induced nitric oxide generation by cultured astrocytoma cells involves a $\mathrm{Ca}^{++}$-calmodulin-independent NO synthase. Biochem. Biophys. Res. Commun. 191:327-334.

25. Feelish, M., and E. Noack. 1987. Nitric oxide (NO) formation from nitrovasodilators occurs independently of hemoglobin or non-heme iron. Eur. J. Pharmacol. $142: 465-469$.

26. Schroder, H., D. C. Leitman, B. M. Bennet, S. A. Waldman, and F. Murad. 1988. Glyceryl trinitrate-induced desensitization of guanylate cyclase in cultured rat lung fibroblasts. J. Pharmacol. Exp. Ther. 245:413-418.

27. Salvemini, D., A. Pistelli, V. Mollace, E. Änggärd, and J. Vane. 1992. The metabolism of glyceryl trinitrate to nitric oxide in the macrophage cell line J774 and its induction by Escherichia coli lipopolysaccharide. Biochem. Pharmacol. 44:17-24.

28. Fostermann, U., H. H. H. W. Schmidt, J. S. Pollock, H. Sheng, J. A. Mitchell, T. D. Warner, M. Nakane, and R. Murad. 1991. Isoforms of nitric oxide synthase. Characterization and purification from different cell types. Biochem. Pharmacol. 42:1849-1857.

29. Bicknell, R., and B. L. Vallee. 1988. Angiogenin activates endothelial cell phospholipase C. Proc. Natl. Acad. Sci. USA. 85:5961-5965.

30. Hearth, W. F., F. Moore, R. Biknell, and B. L. Vallee. 1989. Modulation of mitogenic stimuli by angiogenin correlates with in vitro phosphatidylinositol biphosphate synthesis. Proc. Natl. Acad. Sci. USA. 86:2718-2722.

31. Coughlin, S. R., P. J. Barr, L. S. Cousens, L. J. Fretto, and L. T. Williams. 1988. Acidic and basic fibroblast growth factors stimulate tyrosine kinase activity in vivo. J. Biol. Chem. 263:988-993.

32. Clark, E. R., and E. L. Clark. 1939. Microscopic observations on the growth of blood capillaries in the living mammal. Am. J. Anat. 64:251-299.

33. Diamond, S. L., S. G. Eskin, and L. V. McIntire. 1989. Fluid flow stimulates tissue plasminogen activator secretion by cultured human endothelial cells. Science (Wash. DC). 243:1483-1485.

34. Leibovich, S. J., P. J. Polverini, T. W. Fong, L. A. Harlow, and A. E. Koch. 1994. Production of angiogenic activity by human monocytes requires an L-arginine/nitric oxide-synthase-dependent effector mechanism. Proc. Natl. Acad. Sci. USA. 91:4190-4194.

35. Pipili-Synetos, E., E. Sakkoula, G. Haralabopoulos, P. Andiopuolou, P. Peristeris, and M. E. Maragoudakis. 1993. Evidence that nitric oxide is an endogenous antiangiogenic mediator. Br. J. Pharmacol. 111:894-902. 